\title{
Studi Pemetaan Batimetri Perairan Dangkal Menggunakan Citra Satelit Landsat 8 dan Sentinel-2A (Studi Kasus : Perairan Pulau Poteran dan Gili Iyang, Madura)
}

\author{
Muhammad Wildan Bobsaid. Lalu Muhamad Jaelani \\ Departemen Teknik Geomatika, Fakultas Teknik Sipil dan Perencanaan, Institut Teknologi Sepuluh \\ Nopember (ITS) \\ e-mail:1mjaelani@geodesy.its.ac.id
}

\begin{abstract}
Abstrak-Pemetaan batimetri digunakan untuk memetakan dasar laut. Data dasar laut yang akurat dan terkini sangat dibutuhkan oleh banyak kegiatan manusia seperti untuk rute transportasi air dan konstruksi infrastruktur lepas pantai. Pemetaan in situ secara umum menggunakan echo-sounder memakan waktu, biaya tinggi dan akses yang sulit ke daerah terpencil. Pemetaan batimetri pada perairan dangkal di dekat daerah pesisir juga menghadapi tantangan saat pemetaan in situ sulit dilakukan karena akses kapal survei. Oleh karena itu dalam penelitian ini mencoba untuk mengestimasi perairan dangkal (kurang dari $80 \mathrm{~m}$ kedalaman) menggunakan data satelit penginderaan jauh multispektral dengan memanfaatkan citra Sentinel-2A dan Landsat 8. Data batimetri yang diperkirakan dari satelit ini kemudian divalidasi dengan data pengukuran in situ yang dikumpulkan pada bulan April dan Oktober, 2015. Kisaran kedalaman mutlak yang diperoleh adalah 8,714 12,052 meter untuk Landsat 8 dan 9,220 - 11,149 untuk Sentinel 2. Hasil yang menjanjikan dihasilkan oleh Landsat 8 dengan $N M A E$ sebesar $25,777 \%$ dan rentang kedalaman estimasi yang lebih lebar dibandingkan dengan kedalaman yang didapat oleh Sentinel-2A. Akan tetapi, kedua citra satelit ini tidak bisa digunakan untuk mendapatkan kedalaman yang lebih dalam dari $13 \mathrm{~m}$.
\end{abstract}

Kata kunci-Batimetri Perairan Dangkal, Landsat 8, Sentinel-2A, Algoritma Van Hengel and Spitzer.

\section{PENDAHULUAN}

$\mathrm{P}$ EMETAAN batimetri menjadi hal yang penting yang mendasar untuk memanajemen kawasan pesisir.. Terlebih lagi Indonesia merupakan salah satu negara kepulauan terbesar dengan jumlah 18.108 pulau [1]. Hal ini tentu memberikan prospek sekaligus tantangan bagi pembangunan di Indonesia, terutama wilayah pesisir dan sektor kelautan. Untuk mewujudkan terselenggaranya pemanfaatan potensi kelautan dan pesisir, perlu ditunjang dengan kegiatan dan ilmu hidrografi. Kegiatan utama dalam penerapan ilmu hidrografi di lapangan adalah survei batimetri. Survei batimetri bertujuan untuk menentukan kedalaman untuk memetakan topografi di suatu dasar perairan.

Dewasa ini teknologi penginderaan jauh atau Remote Sensing memberikan peluang untuk pemetaan batimetri perairan dangkal secara efektif dan efisien, terutama untuk daerah yang memiliki tingkat perubahan kedalaman secara cepat. Keuntungan lainnya yaitu dapat dilakukan revisi pemetaan perairan dangkal dengan cepat dan murah [2]. Selain itu daerah cakupan data penginderaan jauh cukup luas sehingga sangat baik untuk mengetahui apa saja yang terjadi di lingkungan sekitarnya, sehingga mudah untuk mengetahui keterkaitan antara satu dengan yang lainnya. Penggunaan teknologi penginderaan jauh untuk pemetaan batimetri ini akan sangat berguna untuk menentukan jalur pelayaran yang aman pada saat kapal berlayar di perairan dangkal. Penggunaan teknologi pengindraan jauh ini selain mudah didapatkan, daerah cangkupannya begitu luas namun masih memiliki resolusi spasial yang baik [3] [4].

Penelitian ini bertujuan untuk mengetahui kemampuan citra satelit multispektral Landsat 8 dan Sentinel-2A dalam mengestimasi dan memetakan perairan dangkal dan mengetahui ketelitian batimetri perairan dengan algoritma Van Hengel and Spitzer menggunakan citra landsat 8 dan sentinel2A terhadap data kedalaman insitu.

\section{METODOLOGI PENELITIAN}

\section{A. Lokasi Penelitian}

Penelitian ini mengambil daerah studi di wilayah sekitar Pulau Poteran yang terletak di antara koordinat $113,94^{\circ}$ BT dan $7,07^{\circ}$ LS sampai $114,06^{\circ}$ BT dan $7,10^{\circ}$ LS dengan zona UTM berada di zona 49S dan 50S, dimana secara administratif berada di Kabupaten Sumenep. Sedangkan untuk Pulau Giliyang terletak antara $114,16^{\circ} \mathrm{BT}$ dan $6,96^{\circ} \mathrm{LS}$ sampai $114,19 \mathrm{BT}^{\circ}$ dan 7,01 LS ${ }^{\circ}$ dengan zona UTM di zona $50 \mathrm{~S}$ yang juga secara administratif berada di Kabupaten Sumenep. 


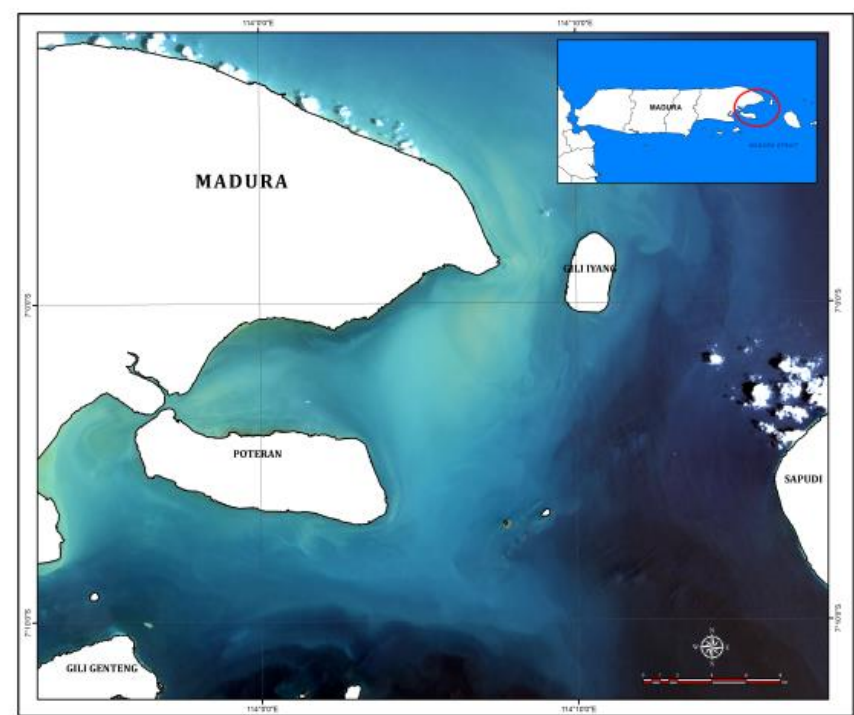

Gambar 1. Lokasi Perairan Pulau Poteran dan Gili Iyang

\section{B. Data dan Peralatan}

Data yang digunakan dalam penelitian ini adalah data insitu kedalaman di perairan Pulau Poteran dan Pulau Giliyang pada bulan April dan Oktober 2015. Sedangkan data citra yang digunakan yaitu data citra satelit Landsat 8 Level 1T (L1T) LC81170652015304LGNOO yang telah terkoreksi geometrik path/row 117/65 dengan waktu akuisisi 31 Oktober 2015 dan data citra satelit Sentinel-2A Level 1C yang sudah terkoreksi geometrik dengan waktu akuisisi data 24 Oktober 2015. Untuk peralatan yang digunakan pada penelitian ini adalah ESA SNAP 5.0 dan ArcGIS 10.3.

\section{Tahapan Pengolahan Data}

Tahapan pengolahan data pada penelitian ini adalah sebagai berikut:

\section{1) Kalibrasi Radiometrik}

Tahap pertama yang dilakukan adalah Kalibrasi radiometrik yaitu melakuakan konversi citra Landsat yang masih tersimpan ke dalam format DN (Digital Number) kedalam format radian TOA (Top of Atmosphere). Koreksi radiometrik (koreksi dan offset variasi data satelit) melibatkan pengolahan citra digital untuk meningkatkan keakuratan besaran nilai kecerahan pada citra. Untuk mengkonversi citra format DN ke radian TOA dapat menggunakan algoritma seperti berikut :

$$
\mathrm{L} \lambda=\mathrm{M} \lambda \times Q c a l+A \lambda
$$

Dimana $\mathrm{L} \lambda$ merupakan TOA spectral radiance, $\mathrm{M} \lambda$ merupakan Band-specific multiplicative rescaling factor, $\mathrm{A} \lambda$ merupakan Band-specific additive rescaling factor, dan Qcal merupakan Quantized and calibrated standard product pixel values $(D N)[5]$.

\section{2) Koreksi Atmosfer}

Koreksi Atmosfer bertujuan untuk mengoreksi efek dari atmosfer yang ada pada data citra yang terukur oleh sensor yang mana akan mempengaruhi akurasi data citra satelit [6]. Koreksi atmosfer pada tahap ini menggunakan parameter koreksi dari hasil simulasi Second Simulation of a Satellite
Signal in the Solar Spectrum-Vector (6SV). Prinsip utama dari koreksi atmosfer 6SV yaitu dengan memasukkan beberapa parameter mengenai tanggal akuisisi citra, model atmosfer, model aerosol, dan visibility pada daerah penelitian untuk mendapatkan koefisien parameter $x a, x b$, dan $x c$ [7][8]. Untuk metode $6 \mathrm{SV}$ dapat menggunakan persamaan :

$$
\begin{gathered}
y=x a \times L \lambda-x b \\
a c r=y(1 .+x c \times y)
\end{gathered}
$$

Dimana acr adalah atmospheric correction reflectance, $L \lambda$ adalah nilai radian $T o A, \operatorname{Rrs} \lambda$ adalah remote sensing reflectance, dan $x a, x b, x c$ adalah koefisien parameter koreksi atmosfer.

Koreksi atmosfer untuk citra Sentinel-2A menggunakan plugin Sen2Cor yang ada di ESA SNAP 5 untuk melakukan konversi data citra Sentinel-2A yang masih Level-1C Top of Atmosphere Reflectance menjadi Level-2A Bottom of Atmosphere Refletance [2]. Pada metode 6SV dan Sen2Cor untuk masing-masing citra akan dibagi dengan $\pi$ untuk mendapatkan $\operatorname{Rrs}(\lambda)$ atau Reflectance Remote Sensing (satuan sr-1 ).

\section{3) Masking}

Masking adalah tahap untuk memisahkan antara daerah perairan dan daratan dengan cara memblok nilai digital number $(D N)$ darat dengan nilai nol. Tahap ini dilakukan agar daerah daratan tidak mempengaruhi perairan pada saat pemasukan algoritma batimetri perairan dangkal. Pada proses masking ini menggunakan metode NDWI (Normalized Difference Water Index) untuk memisahkan daratan dan perairan [9].

$$
N D W I=\frac{(R R S(\lambda R e d)-R R S(\lambda N I R))}{(R R S(\lambda R e d)+R R S(\lambda N I R))}
$$

Dimana $\operatorname{RRS}\left(\lambda_{\mathrm{RED}}\right)$ adalah citra kanal $R e d$ atau kanal 3 untuk citra Landsat 8 dan Sentinel-2A sedangkan $\operatorname{RRS}\left(\lambda_{\text {NIR }}\right)$ adalah citra kanal Near Infrared atau kanal 5 untuk citra Landsat 8 dan kanal 8 untuk kanal Sentinel-2A.

\section{4) Algoritma Van Hengel \& Spitzer}

Setelah kedua citra terkoreksi atmosfer, langkah selanjutnya adalah pengolahan menggunakan Algoritma yang dirumuskan oleh Van Hengel dan Spitzer yang merupakan algoritma transformasi nilai citra satelit untuk menghasilkan nilai kedalaman relatif di perairan dangkal [10]. Pada proses ini, algoritma Van Hengel dan Spitzer dimasukkan kedalam citra Landsat 8 dan Sentinel-2A menggunakan kanal Red green Blue (RGB). Setelah itu akan muncul data kedalaman yang masih relatif pada kedua citra.

$$
\begin{aligned}
& \mathrm{r}=\arctan \left(\mathrm{Ur}+\sqrt{\mathrm{U} r^{2}+1}\right) \\
& \mathrm{s}=\arctan \left(\mathrm{Us}+\sqrt{\mathrm{Us} s^{2}+1}\right) \\
& \mathrm{Ur}=\frac{\operatorname{Var} \mathrm{x} 3+\operatorname{Var} \mathrm{x} 2}{2 \operatorname{Cov} \mathrm{x} 2 \mathrm{x} 3}
\end{aligned}
$$




$$
\mathrm{Us}=\frac{\text { Var } \mathrm{x} 4+\operatorname{Var} \mathrm{x} 2}{2 \operatorname{Cov} \mathrm{x} 2 \mathrm{x} 4}
$$

$\mathrm{Y}=[\cos (\mathrm{r}) \cdot \sin (\mathrm{s}) \cdot \mathrm{X} 2]+[\sin (\mathrm{r}) \cdot \cos (\mathrm{s}) \cdot \mathrm{X} 3]+[\sin (\mathrm{s}) \cdot \mathrm{X} 4]$

Var x2 adalah data varian kanal 2, Var x3 adalah data varian kanal 3, Var $\mathrm{x} 4$ adalah data varian kanal 4, Cov x $2 \times 3$ adalah data kovarian kanal 2 dan 3 dan Cov x2x4 adalah data kovarian kanal 2 dan 4. $r$ dan $s$ adalah nilai sudut rotasi yang dijadikan parameter untuk menghitung nilai indeks kedalaman pada transformasi rotasi yang digunakan pada algoritma Van Hengel dan Spitzer. Y adalah kedalaman relatif (Indeks Kedalaman) dan $\mathrm{Xi}$ adalah nilai reflektan kanal ke-i.

\section{5) Pemodelan Regresi}

Tahap selanjutnya membuat regresi antara nilai kedalaman relatif dari pengolahan citra dengan nilai kedalaman dari data pengukuran dilapangan untuk mendapatkan nilai kedalaman absolut atau nilai kedalaman yang sebenarnya.

\section{6) Uji Validasi}

Setelah didapatkan kedalaman absolut dari kedua citra satelit, selanjutnya dilakukan Uji ketelitian klasifikasi atau validasi data dilakukan untuk mengetahui ketepatan dalam melakukan klasifikasi pada citra terhadap hasil sampel insitu menggunakan Normalized Mean Absolute Error (NMAE). Syarat minimum NMAE yaitu sebesar $\leq 30 \%$ [11].

$$
\text { NMAE }(\%)=\frac{1}{N} \sum\left|\frac{x \text { estimated }, i-x \text { measured }}{x \text { measured }}\right| .100
$$

Xestimated adalah nilai dari estimasi kedalaman absolut yang telah diolah menggunakan regresi dari algoritma Van Hengel and Spitzer, Xmeasured adalah nilai kedalaman hasil pengukuran atau data insitu dan $\mathrm{N}$ adalah jumlah titik sampel yang digunakan.

\section{7) Inverse Distance Weight (IDW)}

IDW merupakan metode interpolasi konvensional yang memperhitungkan jarak sebagai bobot. Jarak yang dimaksud adalah jarak (datar) dari titik data (sampel) terhadap blok yang akan diestimasi. Jadi semakin dekat jarak antara titik sampel dan blok yang akan diestimasi maka akan semakin besar bobotnya, begitu pula sebaliknya. Metode IDW ini digunakan untuk interpolasi kontur terhadap data atau titik-titik kedalaman perairan absolut kedua citra yang sudah tervalidasi [12]. Setelah didapatkannya kontur batimetri maka langkah selanjutnya adalah proses layouting untuk pembuatan peta batimetri perairan Madura Timur.

\section{HASIL DAN ANALISA}

\section{A. Perhitungan Estimasi Kedalaman Relatif Citra}

Citra Landsat 8 yang sudah terkoreksi dan sudah terpisah antara daratan perairannya kemudian dimasukkan kedalam algoritma VHS menggunakan Kanal RGB (Red, Green, Blue) yaitu Kanal 4, 3 dan 2 untuk citra Landsat 8 dan Sentinel-2A. Output dari algoritma ini adalah estimasi kedalaman relatif pada citra satelit. Berikut adalah hasil dari estimasi kedalaman relatif pada citra landsat 8 .

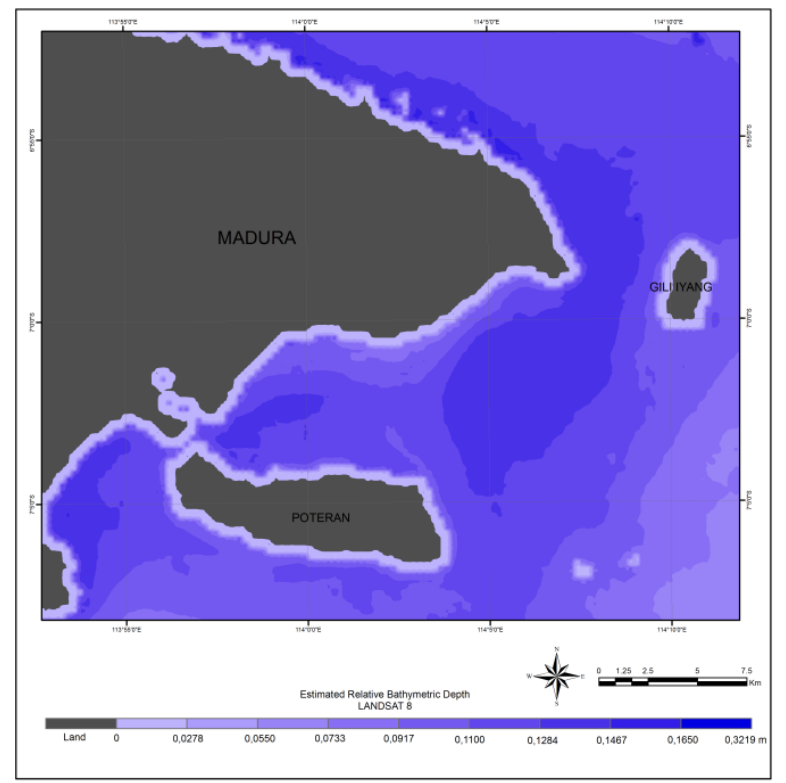

Gambar 2. Estimasi Kedalaman Relatif Menggunakan Citra Landsat 8

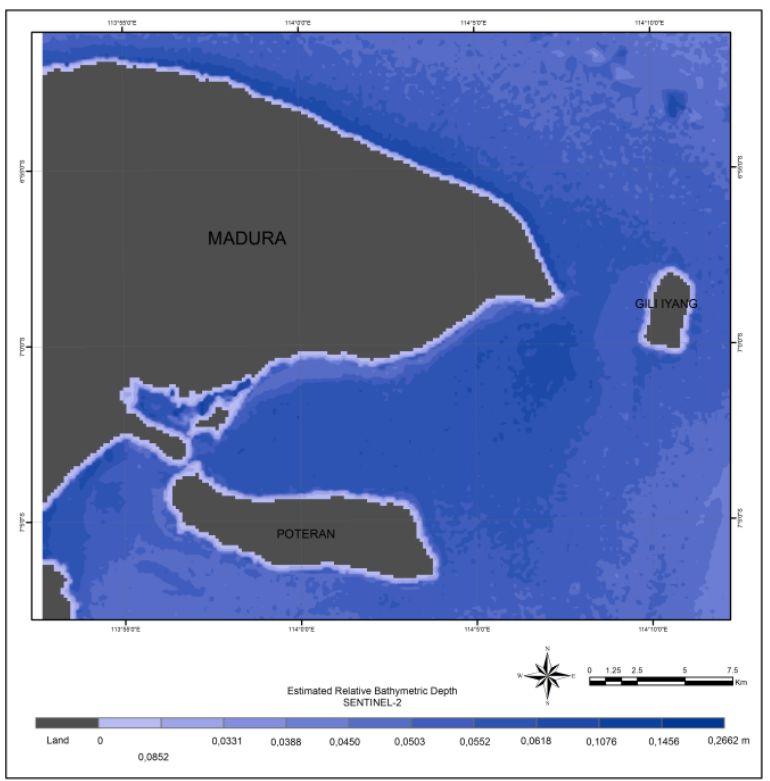

Gambar 3. Estimasi Kedalaman Relatif Menggunakan Citra Sentinel-2A

Dapat dilihat pada gambar 2 dan 3, estimasi kedalaman relatif yang didapat citra landsat 8 berkisar antara $0-0,3219$ meter. Sedangkan estimasi kedalaman relatif yang didapat citra Sentinel-2A berkisar antara $0-0,2662$ meter.

\section{B. Perhitungan Estimasi Kedalaman Absolut Citra}

Kedalaman relatif yang sudah dihitung tersebut harus diubah menjadi kedalaman absolut untuk mendapatkan nilai kedalaman sebenarnya berdasarkan pengolahan citra satelit. Maka dilakakunnya pemodelan regresi antara kedalaman relatif terhadap data insitu untuk mendapatkan nilai estimasi kedalaman absolut. Analisa regresi yang digunakan adalah regresi polinomial orde 2 dengan kanal $R G B$ pada masingmasing citra. Untuk jumlah sampel yang digunakan adalah 60 titik sampel yang tersebar di perairan Pulau Poteran da Gili 
Iyang. Berikut adalah hasil model regresi yang didapat dari data citra Landsat 8 dan Sentinel-2A.

$$
\begin{aligned}
& y=-6519,726\left(K_{\text {Landsat }}\right)^{2}+2660,196\left(K_{\text {Landsat }}\right)-93,633 \\
& y=-8808,089\left(K_{\text {Sentinel }}\right)^{2}+1114,769\left(K_{\text {Sentinel }}\right)-24,122
\end{aligned}
$$

Dimana $\mathrm{KR}_{\text {Landsat }}$ adalah nilai kedalaman relatif dari citra landsat $8, \mathrm{KR}_{\text {Sentinel }}$ adalah nilai kedalaman relatif dari citra Sentinel-2A dan $y$ adalah nilai estimasi kedalaman absolut.

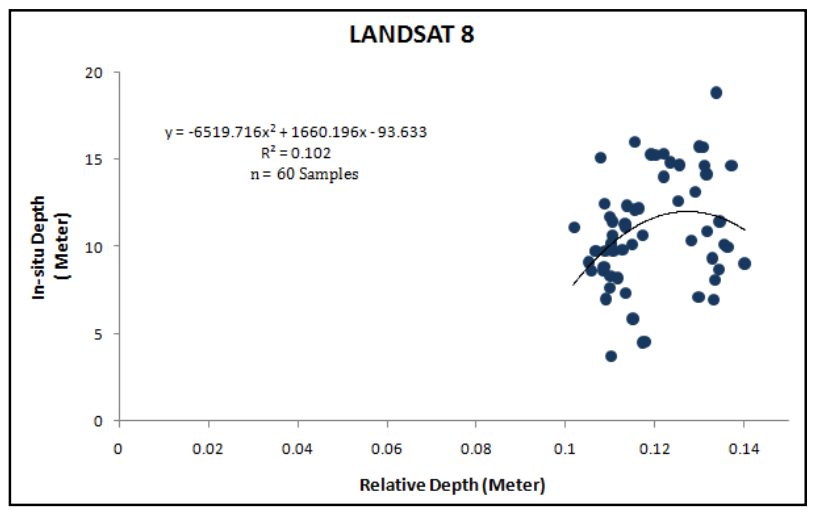

Gambar 4. Model Regresi Estimasi Kedalaman Relatif antara Landsat 8 dan Kedalaman Insitu

Hasil pemodelan regresi ini memiliki nilai korelasi $\left(\mathrm{R}^{2}\right)$ yaitu 0,102 . Berikut adalah hasil model regresi yang didapat dari data citra Sentinel-2A.

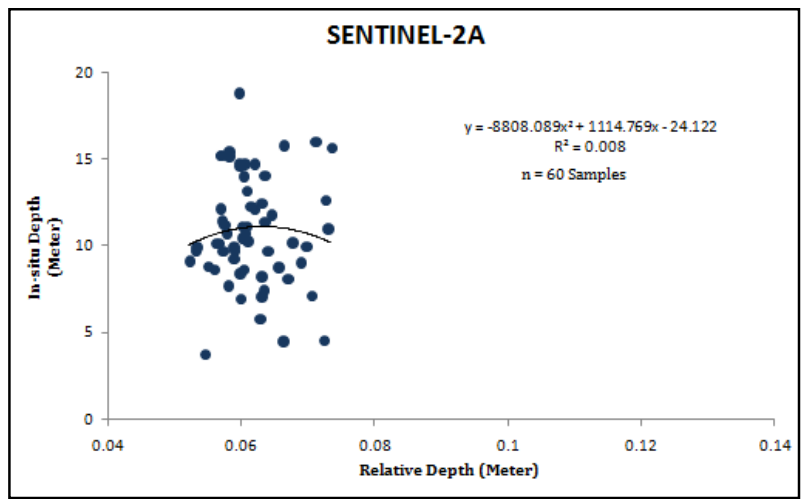

Gambar 5. Model Regresi Estimasi Kedalaman Relatif antara Sentinel-2A dan Kedalaman Insitu

Hasil pemodelan regresi ini memiliki nilai korelasi $\left(\mathrm{R}^{2}\right)$ yaitu 0,008 . Setelah didapat hasil pemodelan regresinya, maka dapat dihitung nilai kedalaman absolut menggunakan regresi masingmasing citra. Berikut adalah hasil dari estimasi kedalaman absolut mengunakan Persamaan regresi (11) dan (12) pada masing-masing citra.
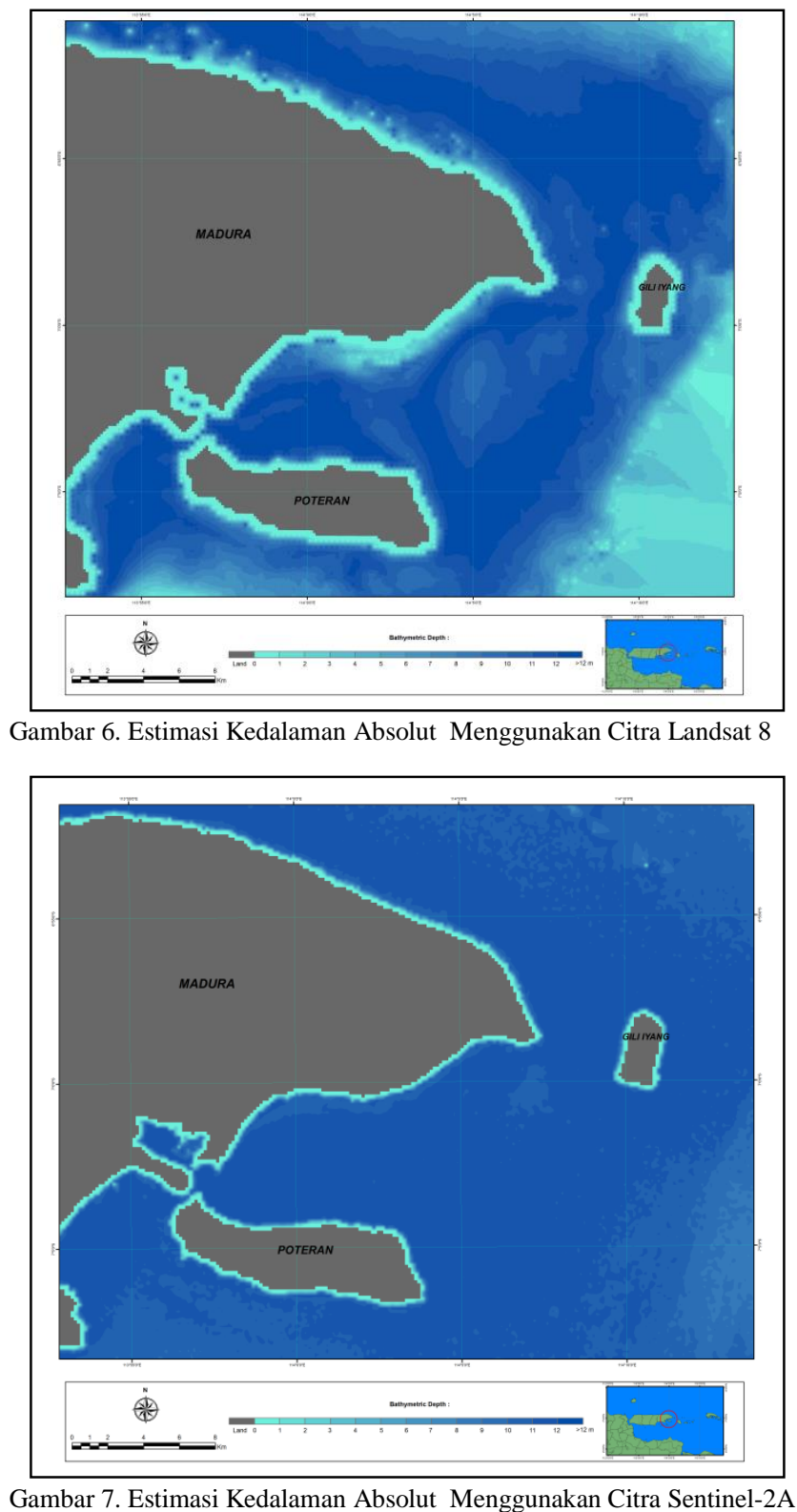

\section{Validasi Estimasi Kedalaman Absolut}

Validasi dilakukan untuk mengetahui sesuai atau tidaknya metode yang digunakan. Nilai yang dihitung adalah sampel acak yang berbeda dari sampel yang digunakan untuk mendapatkan nilai regresinya. Sampel acak digunakan sebagai validasi antara kedalaman absolut dari pemodelan regresi tersebut terhadap kedalaman insitu dengan menggunakan uji validasi NMAE. 


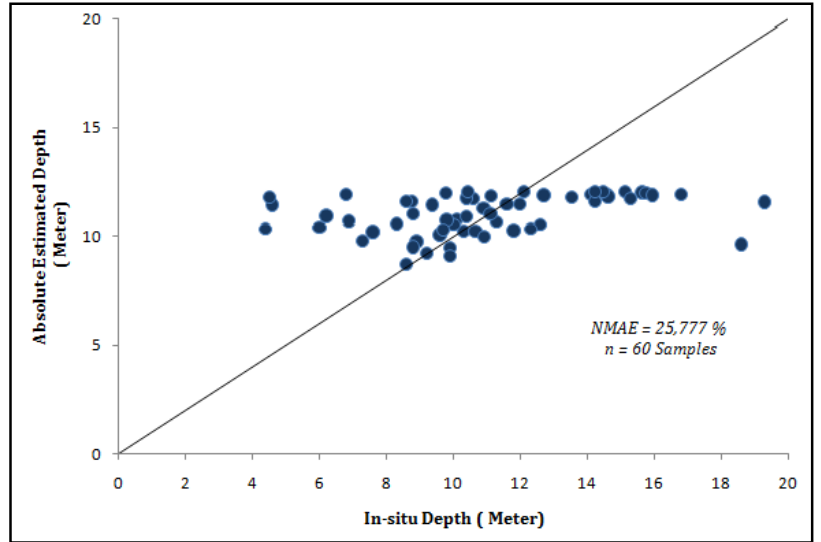

Gambar 8. Akurasi Estimasi Kedalaman menggunakan Citra Landsat 8

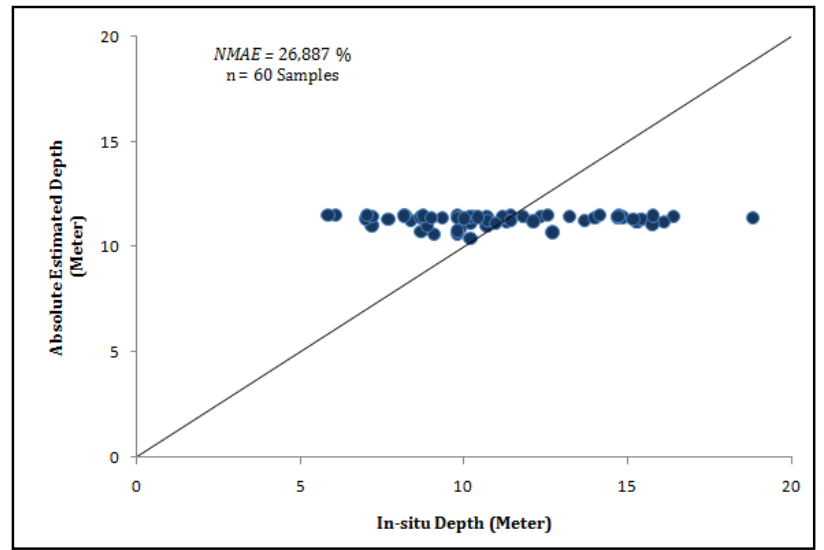

Gambar 9. Akurasi Estimasi Kedalaman menggunakan Citra Sentinel-2A

Gambar 8 dan 9 merepresentasi akurasi data estimasi yang dibandingkan menggunakan data insitu dengan NMAE $25,777 \%$ untuk data citra Landsat dan 26,887\% untuk citra Sentinel-2A. Hasil NMAE mengindikasikan bahwa akurasi data estimasi kedalaman dapat diterima untuk kedua sumber data tersebut.

\section{Hasil Estimasi Kedalaman Perairan pada Kedua Citra Satelit}

Tabel 1.

Data Estimasi Kedalaman Absolut dari Pengolahan Citra Landsat 8 dan Sentinel-2A

\begin{tabular}{cccccc}
\hline \hline Citra & $\begin{array}{c}\text { Kedalaman } \\
\text { Absolut } \\
\text { Satelit } \\
\text { (Meter) }\end{array}$ & $\begin{array}{c}\text { Maksimum } \\
\text { Kedalaman } \\
\text { Absolut } \\
\text { (Meter) }\end{array}$ & $\begin{array}{c}\text { Minimum } \\
\text { Kedalaman } \\
\text { Absolut } \\
\text { (Meter) }\end{array}$ & $\begin{array}{c}\text { Norelasi } \\
\text { antara } \\
\text { Kedalaman } \\
\text { Insitu }\left(\mathrm{R}^{2}\right)\end{array}$ & $\begin{array}{c}\text { NMAE } \\
(\%)\end{array}$ \\
\hline $\begin{array}{c}\text { Landsat } 8 \\
\text { Sentinel- } \\
\text { 2A }\end{array}$ & 11,016 & 12,056 & 8,714 & 0,102 & 25,777 \\
\hline \hline
\end{tabular}

Rentang kedalaman absolut untuk citra Landsat 8 adalah 8,867 - 12, 534 meter dan untuk citra sentinel adalah 10,892 11,478 meter. Estimasi kedalaman absolut yang diolah menggunakan Landsat 8 memiliki rentang kedalaman yang lebih lebar dibandingkan dengan hasil olahan Sentinel-2A (3,342 $\mathrm{m}$ and 1,929 m). Kedua data citra tersebut tidak dapat mengambil data kedalaman lebih dari 13 meter yang mana kedalaman insitu tersebut dapat melebihi 13 meter.

\section{KESIMPULAN}

Berdasarkan dari hasil analisis penelitian ini yang telah dikemukakan, maka dapat diambil kesimpulan sebagai berikut:

1. Citra Landsat 8 memiliki rentang estimasi kedalaman absolut yang lebih baik dibandingkan dengan hasil yang di dapat dari citra Sentinel-2. hal ini juga dikarenakan pada citra Landsat 8 memiliki nilai relektan lebih besar dibandingkan dengan citra Sentinel-2A karena dalam mengestimasi kedalaman menggunakan citra satelit membutuhkan nilai reflektan perairan pada citra satelit. Namun kedua citra satelit ini tidak berhasil mengestimasikan kedalaman absolut lebih dari 13 meter.

2. Nilai Korelasi atau hubungan antara nilai kedalaman absolut yang didapat menggunakan citra Landsat 8 dan Sentinel-2A terhadap nilai kedalaman insitu termasuk rendah yaitu 0,102 untuk Landsat 8 dan 0,008 untuk Sentinel-2A. Hasil validasi estimasi kedalaman menggunakan citra Landsat 8 menunjukkan nilai NMAE yang lebih baik dibandingkan dengan citra Sentinel-2A (25,777\% dan 26,887\%). Dari hasil tersebut dapat mengindikasikan bahwa akurasi data estimasi kedalaman dapat diterima untuk kedua sumber data tersebut namun memiliki nilai korelasi yang lemah antara hasil kedalaman absolut terhadap data kedalaman insitu sehingga perlu dikaji kembali kesesuaian algoritma tersebut.

Saran untuk Penelitian berikutnya adalah perlu adanya kajian lebih lanjut untuk adanya algoritma yang sesuai untuk mengestimasi kedalaman di perairan pulau poteran dan gili iyang untuk citra Landsat 8 dan Sentinel-2.

\section{UCAPAN TERIMAKASIH}

Penulis M. W. B. mengucapkan terima kasih kepada Pusat Studi Kebumian, Bencana dan Perubahan Iklim ITS (PSKBPIITS) yang telah membantu dan mendukung penelitian studi ini.

\section{DAFTAR PUSTAKA}

[1] C. Dkk, "Indonesia as an archipelago: Managing islands, managing the seas," Indones. beyond Water's Edge Manag. an Archipel. State, pp. 1-27, 2009.

[2] E. S. Agency, "Sentinel-2 User Handbook," 2015. [Online]. Available: https://earth.esa.int/documents/247904/685211/Sentinel2_User_Handbook.

[3] D. Lyzenga, "Passive remote sensing techniques for mapping water depth and bottom features," Appl. Opt, vol. 17, no. 3, pp. 83-379, 1978.

[4] D. Lyzenga, "Remote sensing of bottom reflectance and water attenuation parameters in shallow water using aircraft and Landsat data," Int. J. Remote Sens., vol. 2, no. 1, pp. 71-82, 1981.

[5] U. S. G. Survey, "Using the USGS Landsat 8 Product | Landsat Missions," 2013. [Online]. Available: https://landsat.usgs.gov/usingusgs-landsat-8-product.

[6] and F. T. Jaelani L.M., Matsushita, B. Yang, W., "Evaluation of four MERIS atmospheric correction algorithms in Lake Kasumigaura, Japan," Int. J. Remote Sens., vol. 34, no. 24, pp. 8967-8985, 2013.

[7] and A. Jaelani L.M., Setiawan, F., Wibowo, H., "Pemetaan Distribusi Spasial Konsentrasi Klorofil-A dengan Landsat 8 di Danau Matano dan Danau Towuti, Sulawesi Selatan," Pertem. Ilm. Tah. Masy. Penginderaan Jauh Indones., no. 1-8, 2015.

[8] D. Vermote, F, "Second Simulation of the Satellite Signal in the Solar Spectrum, 6S: an overview," IEEE Trans. Geosci. Remote 
Sens., vol. 35, no. 3, pp. 675-686, 1997.

[9] B. Gao, "NDWI-A normalized difference water index for remote sensing of vegetation liquid water from space," Remote Sens. Environ., vol. 58, no. 3, pp. 257-266, 1996.

[10] W. and D. S. Van Hengel, "Multi-temporal water depth mapping by means of Landsat TM," Int. J. Remote Sens., vol. 12, no. 4, pp. 703$712,1991$.

[11] B. Jaelani L.M., Setiawan. F., and Matsushita, "Uji Akurasi Produk Reflektan-Permukaan Landsat Menggunakan Data In situ di Danau Kasumigaura, Jepang," in Pertemuan Ilmiah Tahunan Masyarakat Ahli Penginderaan Jauh Indonesia, 2015, pp. 464-470.

[12] H. Pramono, G, "Akurasi Metode IDW dan Kriging untuk Interpolasi Sebaran Sedimen Tersuspensi di Maros," Forum Geogr., vol. 22, no. 1, pp. 145-158, 2008. 